\title{
FIFTH INTERNATIONAL SYMPOSIUM ON METAL IONS IN BIOLOGY AND MEDICINE
}

\author{
8-10 May 1998 \\ Neuherberg/Munich, Germany
}

http://www.hmi.de/bereiche/N/NG/Events.html

The "Fifth International Symposium on Metal lons in Biology and Medicine" will be held in Neuherberg (Munich), Germany, from 8 to 10 May 1998, as a cooperation between the HahnMeitner-Institut Berlin, Department of Trace Elements in Health and Nutrition and the GSF-National Research Centre for Environment and Health, Institute for Ecological Chemistry, Neuherberg, Germany. This symposium will be aimed to guarantee the free and effective exchange of opinions between specialists working in analysis, research and applications of Metals and Trace Elements in areas of biochemical, biological and medical sciences. It will promote an intensive and productive dialogue between these groups of experts, regarding future collaboration. The scientific program will include plenary and keynote lectures, plattform sessions, posters with discussions and debates.

The first symposium was held in 1990 in Reims, France (chairmen: Ph. Collery and J. C. Etienne) and has been continued every two years: 1992: Loutraki, Greece (chairmen: J. Anastassoupoulou and Th. Theophanides); 1994: Montreal, Canada (chairmen: N. A. Littlefield and L. Poirier); 1996: Barcelona, Spain (chairmen: J. L. Domingo, J. Corbella, J. M. Llobet and Ph. Collery).

The Scientific Committee decided to focus the "Fifth International Symposium on Metal Ions in Biology and Medicine" on the following aspects:

Metals and Environmental Health

Speciation of Metals and Other Elements

Uses of Metals and Selenium in Clinical Applications

Metals and Ageing

Metals and Homeostasis

Effect of Low and High Nutritional Trace Element Intake

Metals and Other Elements Interactions

Assessments of Trace Element Status and Health

Toxicity of Metals

Metals and Hormone Receptions

Metals and Chelation Therapy

Metals and Enzyme Activity

Advanced Methods of Analysis

Language: English

Location: GSF-Forschungszentrum, Neuherberg (15 minutes from Munich, Germany)

Registration fee:

500 DM full (participants), 270 DM (students) (lectures access, final program, proceedings, welcome reception, symposium-dinner and coffee-breaks included)

Reduced rates:

200 DM (one day participants: only coffee-breaks included)

270 DM (retired scientists: welcome reception and coffee-breaks included)

125 DM (accompanying persons: welcome reception, coffee-breaks and conference dinner included)

Special rates:

$10 \%$ reduction for members of the FESTEM

450 DM (full participants for registration before March 1st 1998)

800 DM (registration before March 1st 1998, for participants of both conferences: the preconference "First-Speciation Conference: Trace Element Speciation in Biomedical, Nutritional and Environmental Sciences" [held from 4 to 7 May 1998 also in the GSF-Forschungszentrum, Neuherberg: for more information: Congress service, Postfach 1129, D-85758 Oberschleißheim, Germany, Fax: + 49089 3187-3362, e-mail: schroedel@gsf.de] and the "Fifth International Symposium on Metal lons in Biology and Medicine"

Proceedings: the congress proceedings will be published by John Libbey Eurotext Publishers and indexed in the principal database, including Current Contents 


\section{Preliminary program}

Thursday 7 May 1998

Pre-registration at the Hotel Ibis. Welcome reception

Friday 8 May 1998

Session I: Metals and Homeostasis

R. J. P. Williams, UK, Homeostasis, transport and cellular mechanism of metals

Session II: Toxicity of Metals

F. W. Sunderman, Jr., USA, Teratogenicity and embryotoxicity of metals in humans

Session III: Metals and Enzyme Activity

I. Bremner, UK, Role of metallothionein in cellular metabolism

Session IV: Speciation of Metals and Other Elements

$\mathrm{S}$. Fairweather-Tait, UK, Dependence of the availability on the metal species

Poster session I (with snacks and drinks)

Saturday 9 May 1998

Sessions V and VI: Metals in clinical applications

D. Templeton, Canada, Progress in the safe chelation of iron

R. Cornelis, Belgium, On the importance of the pre-analytical steps in clinical uses of trace element analysis

Sessions VII and VIII: Metals in Clinical Applications

P. Chappuis, France, Copper related diseases

G. Vivoli, Italy, Metals and chronic degeneration diseases

Poster session II (with snacks and drinks)

Congress dinner

Sunday 10 May 1998

Session IX: Clinical Aspects of Selenium-intake

J. T. Salonen, Finland, The role of $\mathrm{Hg}$ and $\mathrm{Se}$, and $\mathrm{Hg}$ and $\mathrm{Fe}$ in lipid peroxidation and human atheriosclerosis

G. F. Combs, Jr., USA, Clinical efficacy of selenium supplements in cancer prevention

J. Neve, Belgium, Bioavailability and safety of selenium supplements

$\mathrm{J}$. Vanderplas, Belgium, Human selenium deficiency and thyroid clinical status

H.-J. Gramm, Germany, Selenium and selenoprotein during the acute inflammatory response. Is there an indication for Se-supplementation in severe sepsis?

Round table (Chair: G. F. Combs, Jr.)

Instructions for the abstracts available from

Dr. Virginia Negretti de Brätter, Organizing Committee

Fifth International Symposium on Metal lons in Biology and Medicine

$$
\text { Hahn-Meitner-Institut Berlin }
$$

Glienicker Str. 100

D-14109 Berlin, Germany

fax: + 4903080622262 or 2781

e-mail: negretti@hmi.de

Deadline for the submission of manuscripts: 2nd March 1998.

The proceedings will be ready at the begin of the symposium.

\section{Registration:}

Mrs. Ulla Schrödel

GSF-Forschungszentrum, Neuherberg, Ingolstädtler Landstraße 1,

D-85764 Oberschleißheim, Germany, Fax: + 49089 3187-3362, e-mail: schroedel@gsf.de)

only for registration

Registration form available under

http://www.hmi.de/bereiche/N/NG/Events.html 